\title{
Resistance of Transgenic Prunus domestica to Plum Pox Virus Infection
}

\author{
M. Ravelonandro, Station de Pathologie Vegetale, INRA, Centre de Recherches de Bordeaux, BP 8133883 Ville- \\ nave d'Ornon, France; R. Scorza, USDA-ARS Appalachian Fruit Research Station, 45 Wiltshire Road, Kearneys- \\ ville, WV 25436; J. C. Bachelier, Station de Pathologie Vegetale, INRA, Bordeaux; G. Labonne, Laboratoire de \\ Zoologie Agricole, ENSAM-INRA, Place Viala, 34000 Montpellier, France; L. Levy, USDA-APHIS, PPQ, Plant \\ Methods Development Laboratory, Bldg. 580, Beltsville, MD 20705; V. Damsteegt, USDA-ARS Foreign Disease- \\ Weed Science Research Unit, Fort Detrick, Frederick, MD 21702; A. M. Callahan, USDA-ARS Appalachian Fruit \\ Research Station, Kearneysville, WV; and J. Dunez, Station de Pathologie Vegetale, INRA, Bordeaux
}

\begin{abstract}
Ravelonandro, M., Scorza, R., Bachelier, J. C., Labonne, G., Levy, L., Damsteegt, V., Callahan, A. M., and Dunez, J. 1997. Resistance of transgenic Prunus domestica to plum pox virus infection. Plant Dis. 81:1231-1235.

Transgenic plum trees (Prunus domestica) containing the plum pox potyvirus coat protein (PPV$\mathrm{CP})$ gene were inoculated with PPV by aphid feeding or chip budding. Infection was monitored by evaluation of virus symptoms, DAS-ELISA, and immunoblot assays. Based on observations and analyses over 3 years including two dormancy cycles, one out of five transgenic clones (C5), was found to be resistant to infection whether inoculated by aphids or by chip budding. PPV could not be detected in any inoculated plants of the C-5 clone by immunoblot or immunocapture-reverse transcriptase-polymerase chain reaction assays. To our knowledge, this is the first P. domestica clone resistant to PPV infection produced by genetic engineering.
\end{abstract}

Sharka disease, where it occurs, is a major constraint to stone fruit (Prunus) production. More than 100 million stone fruit trees are infected in Europe (23). Recently, the disease has been reported in Egypt (21), India (4), and Chile (31). The causal agent is plum pox virus (PPV), a potyvirus that has been widely studied $(15,19,24,38)$. Originally reported from Bulgaria (1), PPV is naturally spread by several aphid species in a non-persistent manner (12). PPV can cause tree death when it occurs in a mixed infection with prune dwarf virus (PDV) or Prunus necrotic ringspot virus (PNRSV) (22). Symptoms of PPV infection include chlorotic spots, rings, and other chlorotic patterns on the leaves, ring patterns on fruit and seed, and mild to severe fruit deformation. Infected fruit are often acidic with low sugar content. Some infected varieties drop their fruit prematurely and these are unsuitable for fresh consumption or processing (8).

There has been considerable effort devoted to the characterization of PPV at the molecular level, notably in the analysis of

Corresponding author: Michel Ravelonandro E-mail address: ravelona@bordeaux.inra.fr

Accepted for publication 29 July 1997.

Publication no. D-1997-0908-01R

(C) 1997 The American Phytopathological Society the genome structure $(15,19,24,38)$ and in the mechanism of virus replication $(20,29,30)$. Immunological $(18,27)$ and molecular (11,16,37,39-41) techniques have been developed for detection of the virus in infected herbaceous and woody species. Considerable attention has been devoted to the development of genetic resistance to PPV in Prunus species $(2,6,7,10,25)$. Varying degrees of tolerance have been described $(2,6,7,10)$ and used in some conventional breeding programs (25). Collections of Prunus germplasm have been screened, yet high levels of natural resistance generally have not been found. Therefore, coat protein (CP)mediated protection (3) via genetic transformation may be useful for the development of resistance to PPV $(14,26,28,34)$.

Transgenic plum trees containing the PPV-CP gene have been shown to accumulate varying levels of PPV-CP RNA and $\mathrm{CP}$ (34). We have previously shown that PPV-CP transgenic clones C-2, C-3, and C4 accumulated high levels of PPV-CP RNA and PPV-CP; C-5 accumulated low levels of RNA and had undetectable CP; C-6 had undetectable levels of both RNA and CP (34). In this report, we describe experiments that indicate that one PPV-CP transgenic plum clone, C-5, is resistant to PPV infection. Transgenic C-5 plants inoculated by aphid feeding or chip budding exhibited no symptoms and have shown resistance to PPV infection during 3 years of evaluation.

\section{MATERIALS AND METHODS}

Plant materials and culture conditions. Buds from transgenic plum clones (C-2 through C-6) containing the PPV-CP gene (34) were grafted onto GF 8-1 'Marianna' $(P$. cerasifera $\times P$. munsoniana $)$ plum rootstocks. Non-transgenic control B70146 and transgenic control EF1 (a clone containing a heterologous $\mathrm{CP}$ gene from papaya ringspot virus) (33) were also grafted onto GF 8-1 rootstocks. Plants were grown in a greenhouse maintained at $22-24^{\circ} \mathrm{C}$ with an $18 \mathrm{~h}$ daylength provided by a mix of natural and supplemental light. Plants were subjected to an artificially induced dormancy cycle by incubating in a $5^{\circ} \mathrm{C}$ cold room for 3 months in the dark. PPV-infected peas (Pisum sativum L. cv. Colmo) and PPV-infected GF305 peach (Prunus persica L. Batsch) were used as inoculum sources (13). Healthy GF305 buds were used as woody indicators of PPV infection. Infection was confirmed by visual symptoms and ELISA. Aphids (Myzus persicae [Sulzer]) were maintained on radish (Raphanus sativus L.)

Aphid inoculation with PPV. Virusfree aphids were starved for $2 \mathrm{~h}$ then given a 10-min acquisition feed on 'Colmo' peas infected with PPV-Barthelasse, a PPV-D serogroup strain selected for its high aphid transmission efficiency (13). Sets of 100 viruliferous aphids were collected and confined by a plastic bag to one shoot tip of each plum tree when the grafted buds had produced shoots $10-30 \mathrm{~cm}$ in length (12). After an overnight inoculation feed, aphids were killed with an insecticide. Inoculated trees were maintained at 22 $24^{\circ} \mathrm{C}, 18 \mathrm{~h}$ daylength. At 12 weeks post inoculation, plants were subjected to a dormancy cycle. Following dormancy, plants were maintained at $22-24^{\circ} \mathrm{C}, 18 \mathrm{~h}$ daylength.

Chip-bud inoculation with PPV. Ten to 12 plants of each transgenic and nontransgenic plum clone were inoculated with two bark chips from GF305 peach infected with a PPV-M serogroup strain collected in Greece selected for its virulence on Prunus (13). The first chip was 
inserted close to the base of the scion and the second chip was inserted into the GF81 rootstock, which is susceptible to PPV infection. One month after inoculation, all plants were subjected to a dormancy cycle. Following dormancy, plants were maintained at $22-24^{\circ} \mathrm{C}, 18 \mathrm{~h}$ daylength.

Symptom expression. The development of visual symptoms of PPV infection was monitored beginning at 3 weeks post inoculation in aphid inoculated plants and at 6 months post inoculation for chip bud inoculated plants.

ELISA detection. Leaves from inoculum sources, from non-transgenic root- stocks, and from GF305 woody indicators were assayed by indirect double-antibody sandwich DAS-ELISA (5) using PPV-CP polyclonal antibody (Sanofi, Libourne, France) and goat anti-rabbit IgG conjugated with alkaline phosphatase (Sanofi, Libourne, France).

Immunoblot assay. Total soluble proteins were isolated from leaves of test plants and resolved by SDS-PAGE (34). The fractionated proteins were transferred to nitrocellulose membrane using a semidry blotting system according to the manufacturer's recommendations (Millipore, Bedford, MA). After transfer, membranes were reacted with the antiserum to PPV helper component (HC) (27) as the primary antibody and goat anti-rabbit IgG conjugate (Jackson, West Grove, PA) as the secondary antibody. The proteins were visualized using the NBT/BCIP system (Promega, Madison, WI).

Immunocapture reverse transcriptase-polymerase chain reaction (IC-RTPCR). Polypropylene microcentrifuge tubes were coated overnight for $3 \mathrm{~h}$ at $37^{\circ} \mathrm{C}$ with a $1: 1,000$ dilution of PPV-CP polyclonal antibody (Sanofi, Libourne, France). Antibody-coated tubes were washed once with PBS-Tween (39). Leaf
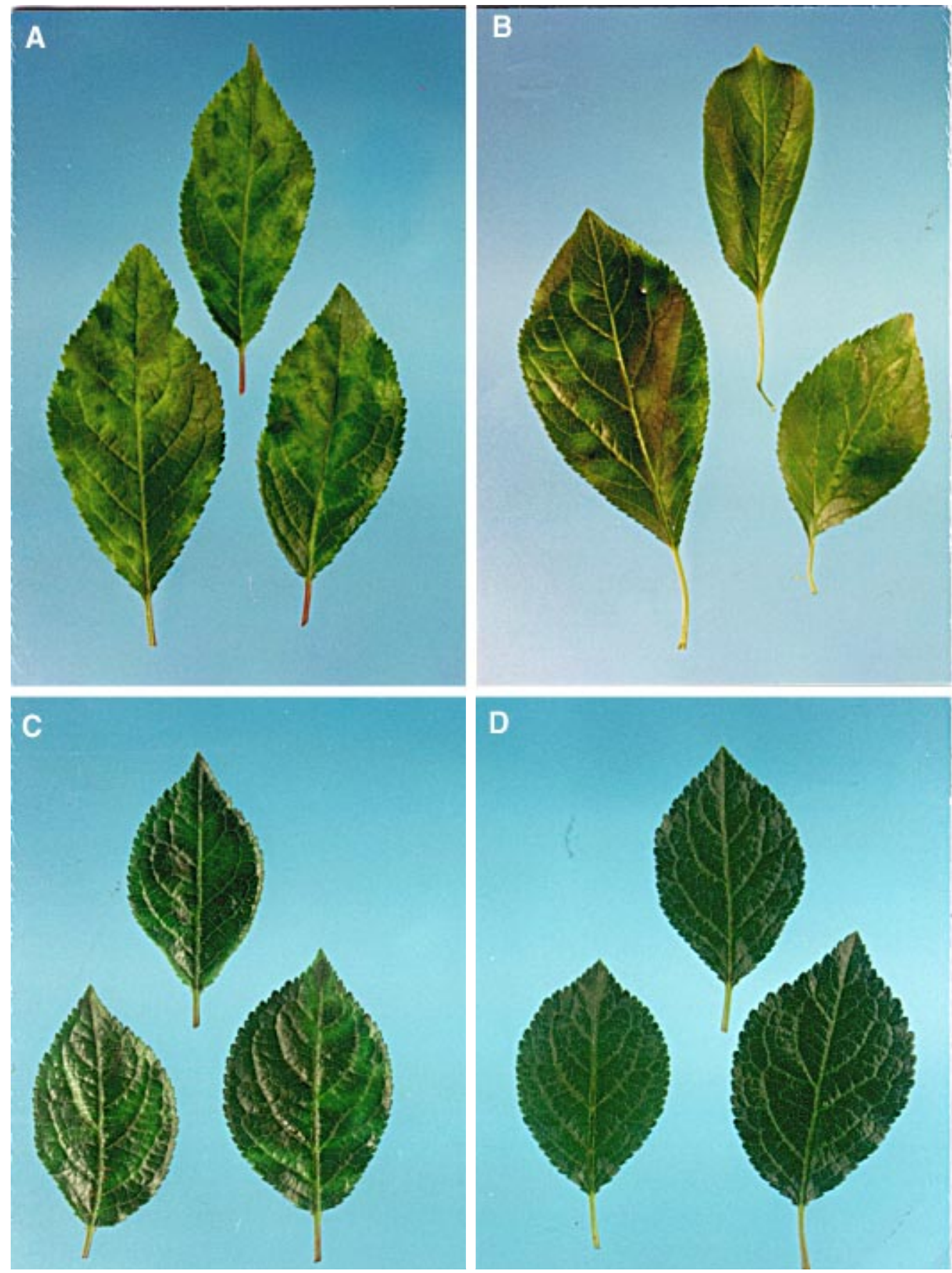

Fig.1. Symptoms of plum pox virus (PPV) infection on leaves of individual PPV-inoculated plants of the susceptible clone C-6 (A), untransformed control B70146 (B), susceptible clone C-2 (C), and resistant clone C-5 (D) 3 months post aphid inoculation feeding. PPV symptoms, distinct chlorotic and necrotic lesions, are visible on the upper leaves in A, B, and C. The leaves of resistant C-5 clone in D do not show symptoms. 
samples were ground in sterile $\mathrm{H}_{2} \mathrm{O}$ at a ratio of $1: 4$, applied to coated tubes, and incubated $3-4 \mathrm{~h}$ at $37^{\circ} \mathrm{C}$. Following antibody capture, the trapped particles were denatured using $0.1 \%$ Triton $\mathrm{X}-100$, and the released viral RNA was reverse transcribed and the cDNA amplified with primers specific to the $\mathrm{C}$-terminal region of the PPV-CP gene (41).

\section{RESULTS}

Aphid inoculation with PPV. At 3 weeks post inoculation, no symptoms were observed on any part of the control or test plant scions. Immunoblotting using antiserum to PPV-HC indicated that the C-5 plants were uninfected but that 51 of 57 of the remaining challenged plants were PPV infected at that time (Table 1). The C-5 plants continued to be symptomless after 10 weeks while 51 of 57 of the remaining inoculated plants showed symptoms (Table 1, Fig. 1) Post-dormancy assays also indicated that all plants except C-5 plants were infected (Table 1). Positive PPV DASELISA of non-transgenic, PPV-susceptible GF8-1 rootstocks using PPV-CP polyclonal antiserum verified that plants had been successfully challenge-inoculated with PPV (Table 1).

Bark chip inoculation with PPV. PPV symptoms were evident in 31 of 61 inoculated plants 6 months post inoculation (Table 2). Immunoblots of total soluble protein extracts reacted with PPV-HC polyclonal antiserum indicated that none of the C-5 plants were infected (Table 2; Fig. 2) but that 39 of the remaining 51 plants were infected (Table 2). Plants that were scored as uninfected were re-inoculated by chip budding. All plants were subjected to a second dormancy cycle and subsequently evaluated for PPV infection by symptom expression and immunoblot assays. These evaluations confirmed the absence of infection in C-5 plants. However, 43 of the 46 remaining inoculated plants were PPVinfected (Table 2). Positive PPV-CP DASELISA of all GF 8-1 rootstocks indicated that chip budding was successful at transferring PPV to inoculated plants (Table 2).

Evaluation of transgenic clone C-5. Plants of clones C-5 and C- 6 were analyzed by IC-RT-PCR. A 243 bp fragment, representing the predicted size of the $\mathrm{C}$ terminal portion of the PPV-CP cistron, was amplified from C-6 but not from C-5 plants (Fig. 3).

In addition, when healthy GF305 buds were grafted onto the PPV-inoculated C-5 scions, no PPV symptoms were observed on the GF305 peach leaves while GF 305 on C-6 had clear symptoms of PPV. These

Table 1. Evaluation of plum pox virus infection in plum clones inoculated by aphid feeding ${ }^{\mathrm{a}}$

\begin{tabular}{|c|c|c|c|c|c|c|c|c|}
\hline \multirow[b]{3}{*}{ Clone } & \multicolumn{4}{|c|}{ Scion predormancy $^{b}$} & \multicolumn{3}{|c|}{ Scion post-dormancy } & \multirow{3}{*}{$\begin{array}{c}\text { Rootstock post-dormancy } \\
6 \text { weeks after bud break } \\
\text { DAS-ELISA } \\
\end{array}$} \\
\hline & \multicolumn{2}{|c|}{3 weeks post-inoculation } & \multicolumn{2}{|c|}{10 weeks post-inoculation } & \multicolumn{2}{|c|}{6 weeks after bud break } & \multirow{2}{*}{$\begin{array}{c}\text { After } 3 \text { yr } \\
\text { Immunoblot }\end{array}$} & \\
\hline & Symptoms & Immunoblot $^{d}$ & Symptoms & Immunoblot & Symptoms & Immunoblot & & \\
\hline $\mathrm{C}-2^{\mathrm{f}}$ & $0 / 8^{g}$ & $8 / 8$ & $8 / 8$ & $8 / 8$ & $6 / 8$ & $8 / 8$ & $8 / 8$ & $8 / 8$ \\
\hline $\mathrm{C}-3$ & $0 / 10$ & $8 / 10$ & $8 / 10$ & $8 / 10$ & $6 / 10$ & $8 / 10$ & $9 / 9$ & $8 / 10$ \\
\hline $\mathrm{C}-4$ & $0 / 12$ & $10 / 12$ & $10 / 12$ & $10 / 12$ & $9 / 12$ & $10 / 12$ & $11 / 11$ & $10 / 12$ \\
\hline $\mathrm{C}-5$ & $0 / 8$ & $0 / 8$ & $0 / 8$ & $0 / 8$ & $0 / 8$ & $0 / 8$ & $0 / 8$ & $0 / 8$ \\
\hline C-6 & $0 / 12$ & $12 / 12$ & $2 / 12$ & $12 / 12$ & $12 / 12$ & $12 / 12$ & $12 / 12$ & $12 / 12$ \\
\hline $\mathrm{EF} 1^{\mathrm{h}}$ & $0 / 8$ & $6 / 8$ & $6 / 8$ & $6 / 8$ & $6 / 8$ & $6 / 8$ & $8 / 8$ & $6 / 8$ \\
\hline B70146 ${ }^{\mathrm{i}}$ & $0 / 7$ & $7 / 7$ & $7 / 7$ & $7 / 7$ & $7 / 7$ & $7 / 7$ & $7 / 7$ & $7 / 7$ \\
\hline
\end{tabular}

a Inoculated with Myzus persicae Sulzer fed on pea cv. 'Colmo' infected with plum pox virus (PPV) D isolate Barthelasse.

b Test plants are a combination of transgenic and non-transgenic scions grafted onto non-transgenic PPV-susceptible GF8-1 rootstocks.

${ }^{c}$ Dormancy in our system is artificially induced by a chilling period of 3 months at $5^{\circ} \mathrm{C}$ in the dark.

${ }^{\mathrm{d}}$ Immunoblot reacted with polyclonal antiserum to PPV helper component.

e DAS-ELISA using polyclonal antiserum to PPV coat protein (CP).

f Clone C-2 through C-6 are CP transgenic clones. Unchallenged C-2 through C-4 clones accumulate PPV-CP, unchallenged C-5 and C-6 clones do not accumulate detectable levels of PPV-CP (see 34).

g Number of plants with symptoms or detectable virus/number of surviving plants tested.

${ }^{\mathrm{h}} \mathrm{EF} 1$ is a plum clone transformed with the CP of papaya ringspot virus (see 33 ).

i Untransformed control plum.

Table 2. Evaluation of plum pox virus infection in plum clones inoculated by chip-budding ${ }^{a}$

\begin{tabular}{|c|c|c|c|c|c|c|}
\hline \multirow[b]{3}{*}{ Clone } & \multicolumn{5}{|c|}{ Scions $^{b}$} & \multirow{3}{*}{$\begin{array}{c}\text { Rootstocks }^{\text {b }} \\
12 \text { months post-inoculation } \\
\text { DAS-ELISA } \\
\end{array}$} \\
\hline & \multicolumn{2}{|c|}{6 months post-inoculation ${ }^{c}$} & \multicolumn{2}{|c|}{12 months post-inoculation ${ }^{d}$} & \multirow{2}{*}{$\begin{array}{c}\text { After } 3 \text { yr } \\
\text { Immunoblot }\end{array}$} & \\
\hline & Symptoms & Immunoblot $^{\mathrm{e}}$ & Symptoms & Immunoblot & & \\
\hline $\mathrm{C}-2^{\mathrm{g}}$ & $3 / 10^{\mathrm{h}}$ & $6 / 10$ & $6 / 9$ & $8 / 9$ & $9 / 9^{\mathrm{i}}$ & $9 / 9$ \\
\hline C-3 & $2 / 8$ & $4 / 8$ & $5 / 8$ & $7 / 8$ & $8 / 8$ & $8 / 8$ \\
\hline $\mathrm{C}-4$ & $4 / 8$ & $6 / 8$ & $4 / 7$ & $6 / 7$ & $7 / 7$ & $7 / 7$ \\
\hline C-5 & $0 / 10$ & $0 / 10$ & $0 / 10$ & $0 / 10$ & $0 / 10$ & $10 / 10$ \\
\hline C-6. & $9 / 10$ & $10 / 10$ & $7 / 7$ & $7 / 7$ & $7 / 7$ & $7 / 7$ \\
\hline$E F 1^{\mathrm{j}}$ & $6 / 7$ & $6 / 7$ & $7 / 7$ & $7 / 7$ & $7 / 7$ & $7 / 7$ \\
\hline B70146 ${ }^{\mathrm{k}}$ & $7 / 8$ & $7 / 8$ & $8 / 8$ & $8 / 8$ & $7 / 7$ & $8 / 8$ \\
\hline
\end{tabular}

a Chip bud source of inoculum was GF305 peach infected with plum pox virus (PPV) M isolate from Greece.

b Test plants were a combination of transgenic and non-transgenic scions grafted onto non-transgenic PPV-susceptible GF8-1 rootstocks. PPV-infected chip buds were inserted into both scions and rootstock.

c $\mathrm{Six}$ month period $=1$ month growth post inoculation at $22^{\circ} \mathrm{C}+3$ months chilling period at $5^{\circ} \mathrm{C}+2$ months regrowth at $22^{\circ} \mathrm{C}$.

$\mathrm{d}$ Twelve month period $=$ two of the cycles in footnote $\mathrm{c}$.

e Immunoblots reacted with polyclonal antiserum to PPV helper component.

${ }^{\mathrm{f}}$ DAS-ELISA using polyclonal antiserum to PPV coat protein $(\mathrm{CP})$.

g Clone C-2 through C-6 are CP transgenic clones. Unchallenged C-2 through C-4 clones accumulate PPV-CP, unchallenged C-5 and C-6 clones do not accumulate detectable levels of PPV-CP (see 34).

${ }^{\mathrm{h}}$ Number of plants with symptoms or detectable virus/number of surviving plants tested.

i A positive immunoblot reaction after three years post inoculation correlated with visual symptoms.

$\mathrm{j}$ EF1 is a plum clone transformed with the CP of papaya ringspot virus (see 33).

${ }^{\mathrm{k}}$ Untransformed control plum. 
data and observations show that clone C-5 is resistant to PPV. Three years post inoculation, C-5 plants remained symptomless and immunoblot negative (Tables 1 and 2).

\section{DISCUSSION}

Aphid and chip-bud inoculations resulted in a high degree of PPV infection in challenged plants (Tables 1 and 2). Of the PPV-transgenic lines tested only line C-5 remained uninfected regardless of inoculation method or sampling date. Molecular analysis of the transgenic C-5 plum clone prior to PPV inoculation had demonstrated that this clone maintained a low level of transcript RNA and did not accumulate detectable levels of CP (34). In addition to clone C-5, clone C-6 did not produce detectable levels of PPV-CP. While both clones appeared to contain an aberrant copy of the PPV-CP gene, clone C-5 also contained intact copies of the PPV-CP gene and accumulated RNA (34). The production of a low level of PPV-CP RNA in C-5 plants, the lack of detectable CP (34), and their resistance to PPV infection appears to be consistent with a post-transcriptional silencing mechanism $(9,17,35)$.

The construction of rootstock/scion combinations using a PPV-susceptible rootstock allowed us to evaluate infection not only in the inoculated scion but also the movement of the virus into the susceptible rootstock. While chip budded plants were inoculated in both the PPV-susceptible GF8-1 rootstock and the test scion, aphid inoculations involved only shoot tips of the test scion. The results of aphid inoculations of C-5 indicated that this clone was effective in block-
A
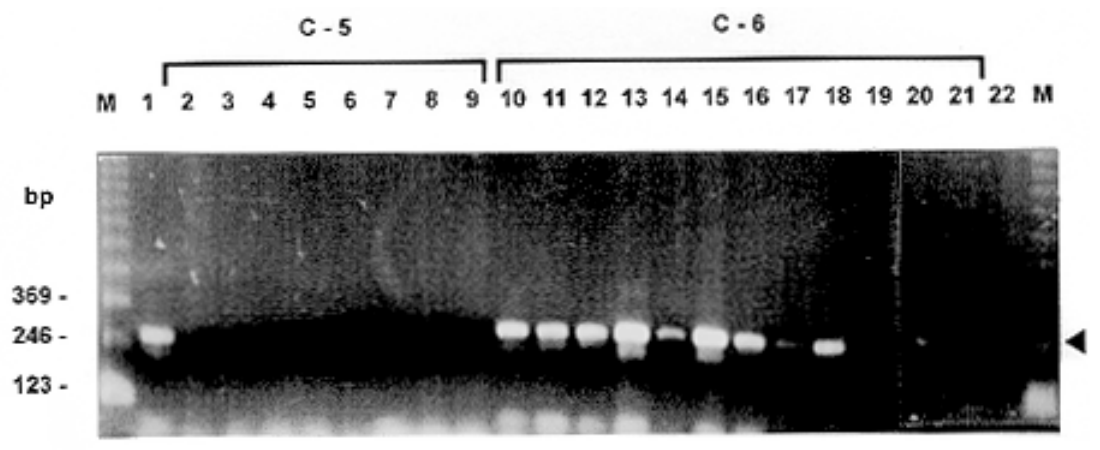

B

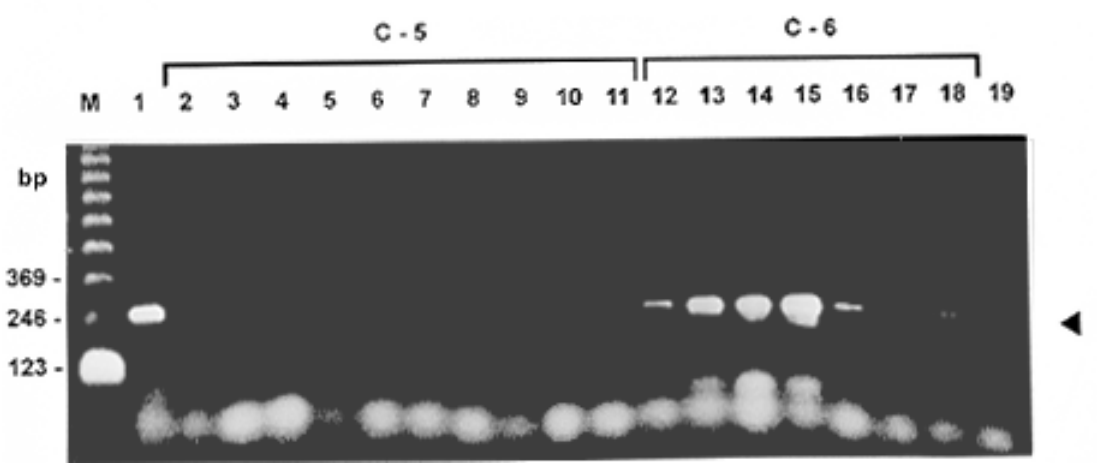

Fig. 3. Agarose gel electrophoresis analysis of immunocapture reverse transcriptase (IC-RT) polymerase chain reactions from plum pox virus (PPV)-challenged transgenic clones C-5 and C-6. Panel A represents analysis of transgenic clones 3 months post aphid inoculation feeding; B represents analysis of transgenic clones 6 weeks after the second cycle of dormancy post chip bud-inoculation. Lane M corresponds to the $123 \mathrm{bp}$ ladder (BRL). In panel A, lanes 1 and 22 represent inoculated and uninoculated, respectively, utransformed control B70146. Lanes 2 through 9 represent inoculated plants of the transgenic clone C-5. Lanes 10-21 represent inoculated plants of transgenic clone C-6. In panel B, lanes 1 and 19 represent inoculated and uninoculated, respectively, untransformed control B70146. Lanes 2 through 11 represent inoculated plants of the transgenic clone C-5. Lanes 12 through 18 represent inoculated plants of the transgenic clone C-6. The arrow indicates the 243-bp fragment from IC-RT-PCR.

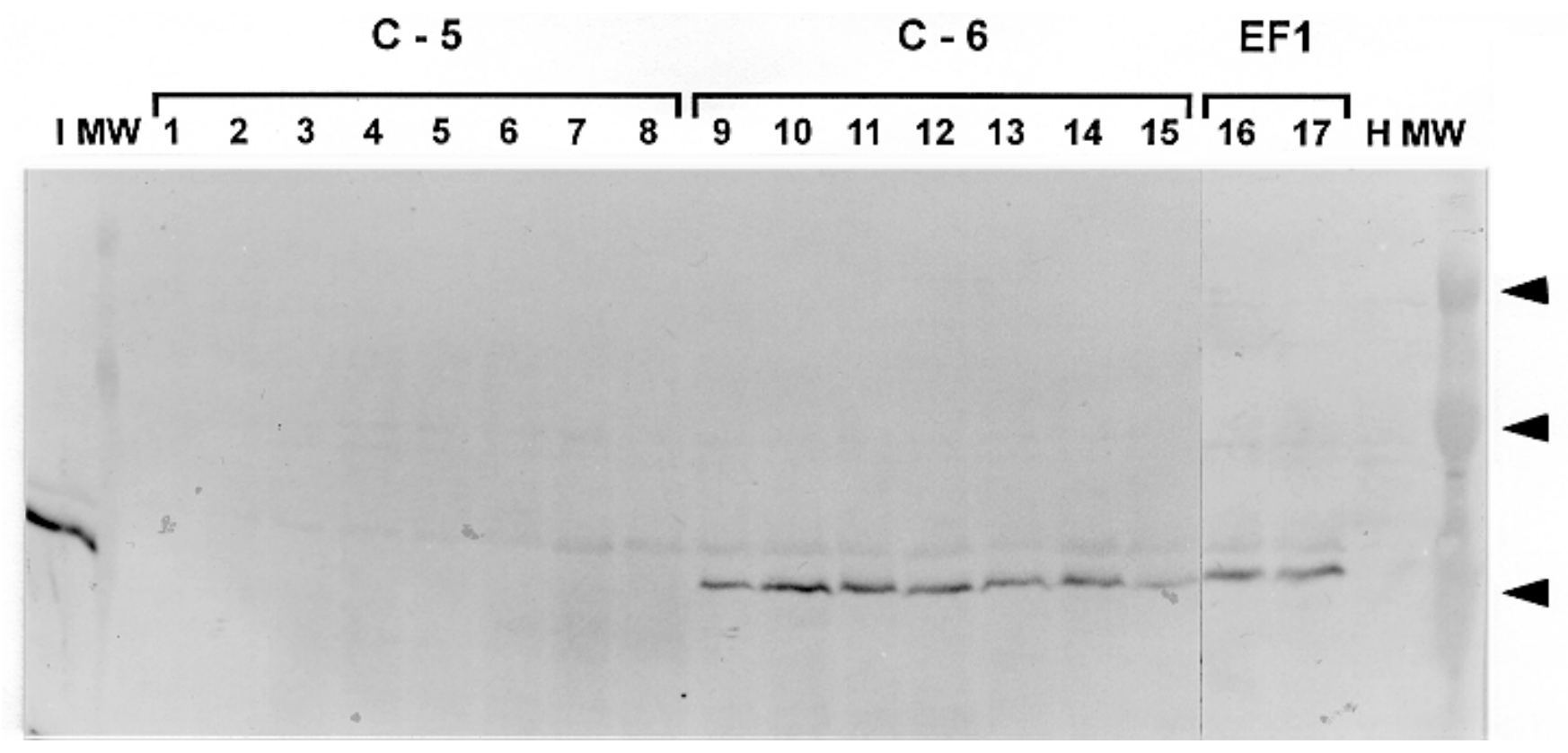

Fig. 2. Immunoblot analysis of plum pox virus (PPV)-challenged transgenic clones C-5, C-6 and EF1 probed with antiserum to the PPV helper component (HC) protein. Lanes I and $\mathrm{H}$ represent inoculated and uninoculated, respectively, untransformed control B70146. Lanes 1-8 represent individual inoculated plants of the transgenic C-5 clone. Lanes 9-15 represent inoculated plants of the transgenic clone C-6. Lanes 16 and 17 represent inoculated plants of transgenic clone $\mathrm{EF} 1$, which contain the heterologous papaya ringspot virus coat protein gene. The arrows (right) indicate 97, 68, and $45 \mathrm{KDa}$. PPV-HC protein is $48 \mathrm{KDa}$. 
ing the transport of PPV into the susceptible rootstock (Table 1).

We have shown that transgenic plum clone $\mathrm{C}-5$ containing the PPV-CP gene is resistant to both the $\mathrm{D}$ and $\mathrm{M}$ strains of PPV. To our knowledge this is the first $P$. domestica clone resistant to PPV produced through genetic engineering. Correlation studies of PPV resistance between transgenic plum lines expressing the PPV-CP gene and those only transcribing the viral transgene are under investigation with a number of additional PPV-CP transformants. Field testing of PPV-CP transgenic plum clones is underway.

Clone C-5 has been cross-hybridized with elite plum genotypes to ascertain if the resistance of the C-5 line can be transferred to the progeny to develop new cultivars selected for fruit quality, productivity, and resistance to PPV. PCR analyses of PPV-CP hybrids have indicated that the PPV-CP gene was transferred to the progeny of the C-5 clone (32). These hybrid plants are currently being evaluated for resistance to PPV. Transgenic clone C-5 may provide a unique source of resistance to PPV for the development of PPVresistant cultivars.

\section{ACKNOWLEDGMENTS}

The work carried out in France was supported by the program INRA 94/5012: AIP-Sharka "Analyse de l'expression du genome et Lutte contre le virus de la Sharka". We acknowledge the assistance of M. Fuchs in construction of the plasmid vector used in this study.

\section{LITERATURE CITED}

1. Atanassov, D. 1932. Plum pox. A new virus disease. Ann. Univ. Sofia, Fac. Agric. Silvic. 11:49-69.

2. Audergon, J. M., Dosba, F., Karayannis I., and Dicenta, F. 1994. Amelioration de l'abricofier pour la resistance à la sharka. OEPP/EPPO Bull. 24:741-748.

3. Beachy, R. N., Loesch-Fries, S., and Tumer, N. E. 1990. Coat protein-mediated resistance against virus infection. Ann. Rev. Phytopathol. 28:451-474.

4. Bhardwaj, S. V., Thakur, P. D., Kohosla, K., and Sharma, D. R. 1995. Detection of plum pox virus in India. Acta Hort. 386:237-240.

5. Clark, M. F., and Adams, A. N. 1977. Characteristics of the microplate method of enzyme linked immunosorbent assay for the detection of plant viruses. J. Gen. Virol. 34:475-483

6. Dosba, F., Lansac, M., and Eyquard, J. P. 1994. Resistance des Prunus à la sharka. OEPP/EPPO Bull. 24:691-696.

7. Dosba, F., Orliac, S., Dutrannoy, F., Masion, P., Massonie, G., and Audergon, J. M. 1992. Evaluation of resistance to plum pox virus in apricot trees. Acta Hortic. 309:211-220.

8. Dunez, J., and Sutic, D. 1988. Plum pox virus. In: European Handbook of Plant Diseases. I. M. Smith, J. Dunez, R. Lelliot, D. H. Phillips, and S. A. Archer, eds. Oxford Blackwell Scientific Publications, Oxford.

9. English, J. J., Mueller, E., and Baulcombe, D. C. 1996. Suppression of virus accumulation in transgenic plants exhibiting silencing of nuclear genes. Plant Cell 8:179-188.
10. Kegler, H., Hartmann, W., Fuchs, E., and Gruntzig, M. 1995. Different host reactions can involve field resistance of plum genotypes to plum pox virus. Acta Hort. 386:306-310.

11. Korschinek, I., Himmler, G., Sagl, R., Steinkellner, H., and Katinger, H. W. D. 1991. A PCR membrane spot assay for the detection of plum pox virus RNA in bark of infected trees. J. Virol. Meth. 31:139-146.

12. Kunze, L., and Krczal, H. 1971. Transmission of sharka virus by aphids. Ann. Phytopathol. HS:255-260.

13. Labonne, G., Ravelonandro, M., Yvon, M., Adamolle, C., Quiot, J. B., and Monsion, M. Evaluation de la resistance d'une lignee transformee de Nicotiana benthamiana à l'inoculation et à l'acquisition du plum pox potyvirus par puceron. OEPP/EPPO Bull. 24:731-740.

14. Laimer da Camara Machado, M., da Camara Machado, A., Hanzer, V., Weiss, H., Regner, F., Steinkellner, H., Mattanovitch, D., Plail, R., Knapp, E., Kalthoff, B., and Katinger, H. D. 1992. Regeneration of transgenic plants of Prunus armeniaca containing the coat gene of plum pox virus. Plant Cell Rep. 11:25-29.

15. Lain, S., Riechmann, J. L., and Garcia, J. A. 1989. The complete nucleotide sequence of plum pox potyvirus RNA. Virus Res. 13:157-172.

16. Levy, L., and Hadidi, A. 1994. A simple and rapid method for processing tissue infected with plum pox potyvirus for use with specific 3' non-coding region RT-PCR assays. OEPP/EPPO Bull. 24:595-604.

17. Lindbo, J. A., and Dougherty, W. G. 1992. Pathogen-derived resistance to a potyvirus: Immune and resistant phenotypes in transgenic tobacco expressing altered forms of a potyvirus coat protein nucleotide sequence. Mol. Plant-Microbe Interact. 5:144-153.

18. Lopez-Moya, J., Sanz, A., Cambra, M., Gorris, M. T., Anaya, C., Miguet, J., Cortes, E., and Lopez-Abella, D. 1994. Production and characterization of plum pox virus monoclonal antibodies and their use for differentiation of Mediterranean isolates. Arch. Virol. 5:293-304

19. Maiss, E., Timpe, U., Brisske, A., Jelkmann, W., Casper, R., Himmler, G., Mattanovitch, D., and Katinger, H. W. D. 1989. The complete nucleotide sequence of plum pox virus RNA. J. Gen. Virol. 70:513-524.

20. Maiss, E., Timpe, U., Brisske-Rode, A., Lesemann, D. E., and Casper, R. 1992. Infectious in vivo transcripts of a plum pox potyvirus full-length cDNA clone containing the cauliflower mosaic virus 35S RNA promoter. J. Gen. Virol. 73:709-713.

21. Mazyad, H. M., Nakhla, M. K., Abo-Elela, A., and El-Hammady, M. H. 1992. Occurence of plum pox (sharka) virus on stone fruit trees in Egypt. Acta Hort. 309:119-124.

22. Nemeth, M. 1986. Virus, Mycoplasma and Rickettsia Diseases of Fruit Trees. Martinus Nijhoff Publishers, Dordrecht.

23. Nemeth, M. 1994. History and importance of plum pox in stone-fruit production. OEPP/ EPPO Bull. 24:525-536.

24. Palkovics, L., Burgyan, J., and Balazs, E. 1993. Comparative sequence analysis of four complete primary structures of plum pox virus strains. Virus Genes 7:339-347.

25. Rankovic, M., Paunovic, S., and DulicMarkovic, I. 1995. Current situation and future trends in solving sharka problem in F.R. Yugoslavia. Acta Hort. 386:241-247.

26. Ravelonandro, M., Monsion, M., Delbos, R., and Dunez, J. 1993. Variable resistance to plum pox virus and potato virus $\mathrm{Y}$ infection in transgenic Nicotiana plants expressing plum pox virus coat protein. Plant Sci. 91:157-169.

27. Ravelonandro, M., Peyruchaud, O., Garrigue, L., de Marcillac, G., and Dunez, J. 1993. Immunodetection of the plum pox virus helper component in infected plants and expression of its gene in transgenic plants. Arch. Virol. 130:251-268

28. Regner, F., da Camara Machado, A., Laimer da Camara Machado, M., Steinkellner, H., Mattanovitch, D., Hantzer, V., Weiss, H., and Katinger H. W. D. 1992. Coat protein mediated resistance to plum pox virus in Nicotiana clevelandii and N. benthamiana. Plant Cell Rep. 11:30-33.

29. Riechmann, J. L., Cervera, M. T., and Garcia, J. A. 1995. Processing of the plum pox virus polyprotein at the P3-6KI junction is not required for virus viability. J. Gen. Virol. 76:951-956.

30. Riechmann, J. L., Lain, S., and Garcia, J. A. 1992. Highlights and prospects of potyvirus molecular biology. J. Gen. Virol. 73:1-16.

31. Roy, A. S., and Smith, I. M. 1994. Plum pox situation in Europe. OEPP/EPPO Bull. 24:515-523.

32. Scorza, R., Levy, L., Callahan, A. M., Damsteegt, V., and Ravelonandro, M. 1997. Transferring potyvirus coat protein genes through hybridization of transgenic plants to produce plum pox virus resistant plums (Prunus domestica L.). Proc. 17 Int. Symp. on Virus and Virus-Like Diseases of Temperate Fruit Crops, June 23-27, 1997, Bethesda, MD.

33. Scorza, R., Levy, L., Damsteegt, V., Yepes, L. M., Cordts, J., Hadidi, A., Slightom, J., and Gonsalves D. 1995. Transformation of plum with the papaya ringspot virus coat protein gene and reaction of transgenic plants to plum pox virus. J. Am. Soc. Hort. Sci.

34. Scorza, R., Ravelonandro, M., Callahan, A. M., Cordts, J. M., Fuchs, M., Dunez, J., and Gonsalves, D. 1994. Transgenic plums (Prunus domestica) express the plum pox virus coat protein gene. Plant Cell Rep. 14:18-22.

35. Smith, H. A., Swaney, S. L., Parks, T. D., Wermsman, E. A., and Dougherty, W. G. 1994. Transgenic plant virus resistance mediated by untranslated sense RNAS: expression, regulation and fate of nonessential RNAS Plant Cell 6:1441-1453.

36. Teycheney, P. Y., Tavert, G., Delbos, R. Ravelonandro, M., and Dunez, J. 1989. The complete nucleotide sequence of plum pox virus RNA (strain D). Nucleic Acids Res. 17:10115-10116.

37. Varveri, C., Candresse, T., Cugisi, M., Ravelonandro, M., and Dunez, J. 1988. Use of a ${ }^{32} \mathrm{P}$ labeled transcribed RNA probe for dot hybridization detection of plum pox virus. Phytopathology 78:1280-1283.

38. Varveri, C., Ravelonandro, M., and Dunez, J. 1987. Construction and use of a cloned cDNA probe for the detection of plum pox virus in plants. Phytopathology 77:1221-1224.

39. Wetzel, T., Candresse, T., Macquaire, G., Ravelonandro, M., and Dunez, J. 1992. A highly sensitive immunocapture polymerase chain reaction method for plum pox potyvirus detection. J. Virol. Meth. 39:27-37.

40. Wetzel, T., Candresse, T., Ravelonandro, M., Delbos, R., Mazyad, H., Aboul-Ata, A. E., and Dunez, J. 1991. Nucleotide sequence of the 3 terminal region of the El Amar strain of plum pox potyvirus. J. Gen. Virol. 72:1741-1746.

41. Wetzel, T., Candresse, T., Ravelonandro, M., and Dunez, J. 1991. A polymerase chain reaction assay adapted to plum pox virus detection. J. Virol. Methods 33:355-365. 